\title{
ANCIENT CORE-PERIPHERY INTERACTIONS: LOWER NUBIA DURING MIDDLE KINGDOM EGYPT (CA. 2050-1640 B.C.) ${ }^{1}$
}

\author{
Roxana Flammini \\ Centro de Estudios de Historia del Antiguo Oriente \\ Universidad Católica Argentina \\ rflammini@uca.edu.ar
}

\begin{abstract}
This paper applies the core-periphery theoretical framework as an attempt to explain the nature of the Egyptian intervention in Lower Nubia and the subsequent sociopolitical status the region acquired during the Middle Kingdom (ca. 2050-1640 BC) through consideration of the ideological bias held by the Egyptian State along with its economic and political goals.
\end{abstract}

\section{INTRODUCTION}

Since the publication of The Modern World System the categories that Wallerstein (1974) generated in order to explain the emergence of capitalism in Western Europe have been tested to describe pre-modern world-systems. Critical observations made to the original model - like those of Schneider (1977) - and theoretical accommodations to particular historical situations also began a few years after the publication of the original theory. In fact, Wallerstein's three assumptions: of core dominance on the peripheries; of inherently asymmetrical exchange between regions; and of trade as the prime mover of social development could not always be proven to take place in pre-modern societies.

Several of these theoretical approaches were related to the ancient Near Eastern polities' relationships (Chase-Dunn and Hall 1991; Kardulias 1996; Kohl 1987; Rowlands 1987; Stein 1999). In particular, Rowlands (1987) called attention to the anachronisms that could arise in the applications of these categories to non-capitalist societies and proposed an analysis based on the exchange of luxuries rather than staples. Kohl (1987), on the other hand, argued that multiple core areas co-existed and made direct contact with each other. In addition, he pointed out that in ancient societies the dependence relationships between cores and peripheries were rather weak

${ }^{1}$ I wish to express my gratitude to the Journal of World-Systems Research's anonymous reviewers, for their useful comments and bibliographic suggestions. I thank Juan Manuel Tebes for reading an earlier draft of this paper. It is also my pleasure to thank Tracy Musacchio for correcting my English. All errors are, however, my responsibility. Direct all correspondence to: Roxana Flammini, Centro de Estudios de Historia del Antiguo Oriente, Universidad Católica Argentina, Av. Alicia Moreau de Justo 1500PB (C1107AFD), Buenos Aires, Argentina. Phone: (54-11) 4349-0200 ext. 1189. 


\section{JOURNAL OF WORLD-SYSTEMS RESEARCH}

and unstable, and that peripheries possessed a great deal of technological innovations. In this regard, Kohl was against diffusionist hypotheses in which cores are visualized as large cultural and technological givers, and peripheries as mere receptors of such "developments" (Kohl 1987). In fact, technology spread fairly quickly in the Ancient Near East, and there were not extreme differences between cores and peripheries in regard to this aspect. Occasionally, technological innovation occurred in a peripheral area and reached a core area afterwards.

One of the main issues is that many ancient core-periphery relationships do not fit into a core-driven model. In this regard, Chase-Dunn and Hall (1991) introduced several revisions to world-systems theory, defining two types of core-periphery relationships: first, core-periphery differentiation "in which societies at different levels of complexity and population density are in interaction with each other within the same world-system," without exploitation by the core; and second, core-periphery hierarchy "which will be understood to mean the existence of political, economic or ideological domination between different societies within the same world-system" (Chase-Dunn and Hall 1991:19). They also introduced a more specific definition for the category of semi-periphery. To them, semi-periphery is any area geographically located between cores and peripheries that acted as mediator in the relationships between the core and the periphery. One related aspect is that its political organization showed a complex mixture of aspects from both cores and peripheries (Chase-Dunn and Hall 1991).

Furthermore, they developed a preliminary typology of world-systems based on the neoMarxian modes of production (Wolf 1982): (1) kin-ordered, normatively-based; (2) tributary, politically coercive, state-based; and (3) capitalist, economically coercive, state-based (ChaseDunn and Hall 1991; Hall 1999).

Besides the attempts to adjust theoretical issues, specific research from the world-system framework that could be applied to ancient Near Eastern societies was carried out on the expansion of Mesopotamian Uruk during the third millennium B.C. by Algaze (1993). He argued that primary states involved in processes of external expansion could be characterized as early examples of economic imperialism (Algaze 2001). Algaze's conclusions regarding an early Mesopotamian Empire comparable to the modern world-system were revised by Stein (1999) who suggested instead two different theoretical frameworks to analyze the Uruk expansion, namely the distance-parity and the trade-diaspora models. Others, like Rothman (2001), disagreed with Algaze's interpretation of the data.

Egyptologists are not often amenable to this kind of explanation, although many researchers of Nubian-Egyptian relationships have explained the link by using some variety of the core-driven core-periphery model (Adams 1977; Emery 1965; Kemp 1978; Trigger 1976). In these approaches, typically the core (Egyptian) dominion extended over a subordinated (Nubian) periphery. In fact, the idea of the superiority of Egypt comes from the oldest approaches, which considered mistakenly Kerma - an important node of exchange during the period under consideration, located at the Third Cataract - to be an Egyptian colony founded by the kings of the $12^{\text {th }}$ Dynasty (Reisner 1923a, b; for the new dates of the Kushite elite's tombs see Gratien 1978). As Smith (2003) rightly points out, theoretical models that emphasize the core dominion downplay native agency. Nevertheless, Kerma is a completely Nubian site as its material culture demonstrates (Bonnet 1986; Bonnet 2000).

To be certain, it is extremely difficult to define the political status of Kerma because of the lack of textual sources. Many researchers define Kerma as a state as early as the Middle Kerma period, but more research is necessary to define this specific issue. It is highly plausible 
that Kerma exhibited a highly stratified kinship society during the Middle Kerma period and that the state emerged in a later historical situation (perhaps during the Classic Kerma phase). ${ }^{2}$

Whenever Kerma began to meet our definition of a state, this does not stop us from focusing on the characteristics of the relation between Egypt and Kerma as a core-periphery relationship. Following the Chase-Dunn and Hall (1991) schema, this relationship fits into a coreperiphery differentiation for a long period, then shifts to a core-periphery hierarchy in later times. In the period we shall consider here, Egypt's Middle Kingdom, their relationship was a coreperiphery differentiation since the core (Egypt) did not exert any kind of exploitation or domination on the periphery (Kerma).

Moreover, a point that deserves serious consideration and that possibly may help to understand this situation is the idea of an asymmetrical relationship between cores and peripheries. Certainly, this relationship should not be understood to mean that the core performs an active role, whereas the periphery is just a passive agent - which, as it has been noted, may lead to simplistic explanations - but rather this relationship is one in which both partners mutually influence each other. The particular features of this asymmetry would exist because many economic, ideological, or even political practices had a different level of relative impact. In other words, these practices originated from the core area and reached the periphery, while the same is not true for the inverse situation.

In this schema, Lower Nubia played a key role as an intermediary during the Middle Kingdom. Here we shall consider two main dimensions regarding this point: first, a reconsideration of the role that the state ideology played in the core area and its involvement in the way Egyptians considered Lower Nubia; and second, the sociopolitical status Lower Nubia acquired through its relationship with the core and the periphery. These considerations are based on a reevaluation of the archaeological remains and the (Egyptian) textual evidence.

\section{THE EGYPTIAN ADVANCE OVER LOWER NUBIA DURING THE MIDDLE KINGDOM}

The Nile was the main axis of exchange in northeast Africa during ancient times. At the southern limit of the ancient Egyptian State, the Nubian territory began and extended from Elephantine to the lands south of the Fourth Cataract, or perhaps even farther. These territories were crossed by the Nile, which provided a natural corridor from the heart of Africa to the Mediterranean Sea. The ancient Egyptian territory, named Kemet by the ancient Egyptians, had very specific geographic boundaries: to the North, the Mediterranean Sea; to the South, the First Cataract, at Elephantine; to the East, the Red Sea; and to the West, the mountains of the western desert. Also, Egyptians recognized two "sacred lands": one to the South, Punt, and another to the North, Lebanon (Hornung 1992:74). The borders of the Egyptian State were not fixed as the king had the capability to establish new boundaries.

${ }^{2}$ O'Connor (1991; 1993) defines Kerma as a highly developed kinship society or even a state. But in fact, the mode of social articulation of kinship societies is quite different from that of state societies. The first articulates through inner consensus, while state societies articulate upon the legal monopoly of the force sustained by a segment of the society (Campagno 2002). 


\section{JOURNAL OF WORLD-SYSTEMS RESEARCH}

The ancient Egyptian texts distinguish many spatial ambits to the south of Elephantine, but we shall focus on two of them: Wawat and Kush, identified in a simplified way as Lower and Upper Nubia respectively (Adams 1977). The advance of the Egyptian State during the Middle Kingdom took place over the first of the two.

Lower Nubia (Wawat) extended between the First Cataract and an area named Batn elHagar (The Belly of the Rock), which is a narrow river strait located south of the Second Cataract. The area was inhabited by the sedentary Nubian C-Group, identified with the nehesyw mentioned in Egyptian sources (Schneider 2003).

Another Nubian group, the medjayw of the Egyptian texts, was semi-nomadic and lived in the Eastern desert. This group is commonly identified with the Pan Grave cultural remains (Lacovara 1997; Sadr 1987, 1990; Schneider 2003). Upper Nubia (Kush) likely extended south of the Batn el-Hagar to the Fourth Cataract or farther and, as we mentioned before, the main city of the area was Kerma, located at the Third Cataract.

The relationship between Egyptians and Nubians is documented from the Early Dynastic period through the exchange of prestige goods (Campagno 2004b), but it is difficult to reconstruct the way in which the contact took place. During the Old Kingdom (ca. 2800-2200 B.C.) information becomes more abundant. The Egyptian State sent peaceful commercial expeditions into Nubia (for instance, that of Herkhuf), and carried out punitive actions (such as those registered in the Palermo Stone). Egyptians also built a settlement near the Second Cataract, Buhen, (Adams 1977) probably during the $2^{\text {nd }}$ dynasty but it is not known if it was continuously occupied. Most of the evidence comes from the $4^{\text {th }}$ and $5^{\text {th }}$ dynasties, when the names of many kings appeared at this settlement. The settlement could be related to copper smelting during that time; in fact, it was a walled enclosure surrounding a terraced town with magazines and workshops (Morkot 2000). It does not seem that there were polities in Nubia (neither Lower nor Upper Nubia) menacing the Egyptian presence in the southern territories, so the Egyptians could travel freely through the southern lands without strengthening their presence through a permanent and articulated control over the Nubian population. At that time, Lower Nubia was inhabited by the Nubian A-Group while Kerma was probably a reduced sedentary settlement without the sociopolitical connotations it acquired in later times. Anyway, Kerma was a stratified society which maintained exchanges with Egypt and the territories located to its south, as the prestige objects found in its necropolis demonstrate (Bonnet 1986). During the disruptive period known as the First Intermediate Period (ca. 2200-2050 B.C.), the Egyptian State suffered a decentralization process which led to a sociopolitical crisis. During this time, Egypt did not maintain relationships with its southern neighbors.

But once the recentralization process succeeded after the First Intermediate Period, the Egyptian State initiated an effective and permanent occupation of Lower Nubia. This is attested from the beginning of the $12^{\text {th }}$ Dynasty through the reign of Sesostris III (ca. 1975-1850 B.C.), when a chain of fortresses were founded from Elephantine to Semna South. These fortresses were maintained under Egyptian control until the late $13^{\text {th }}$ Dynasty.

In addition to constructing fortresses, Egyptians rebuilt preexisting sites (such as Buhen) and erected other constructions, such as the walls that extended between Aswan and Konoso (Philae) (Gardiner 1916) and between Uronarti and Semna (Mills 1967-68). It is plausible that some of the buildings inside the fortresses were temporary palaces, like the structures found at Kor and Uronarti that followed a ritual orientation to the north. Others are plausibly temples, as the building found under the temple built at Buhen during the reign of Hatshepsut seems to be 
(Kemp 1985). Additionally, there was a system of communication between the fortresses, demonstrated by many outposts found near the Nile banks (Fig. 1).

In addition to these building activities, it is worth mentioning the opening of a channel known as "Beautiful are the ways of Khakaure, eternally" in the vicinity of the First Cataract during Sesostris III's reign (Inscription of the Keeper of the Treasure Senankh, year 8 of Sesostris III). This channel made it navigable for Egyptian boats to sail the Nile during the whole year (Vandersleyen 1995; see also Quirke 1990).

We can reconstruct two different stages in the advance over Lower Nubia: first, the $12^{\text {th }}$ Dynasty's early kings reached the Second Cataract; and second, Sesostris III advanced beyond this point, on the section of the river known as Batn el Hagar, reaching as far as Semna. With Sesostris III's ascent to the throne, a new stage in the policy of tightening Egyptian control over Nubia was inaugurated.

Fortunately, our knowledge of the fortresses system is not restricted to the archaeological remains, which disappeared once the Aswan High Dam was erected. In fact, the Egyptian fortresses in Lower Nubia were mentioned in the so-called Onomasticon Papyrus, a document that lists fourteen toponyms from Semna South to the North. Many of these sites were identified with the archaeological remains of the fortresses, particularly Semna South, Semna, Kumma, Uronarti, Shelfak and Askut. Beyond the narrow passage at the Second Cataract, it mentions the Egyptian names of the fortresses identified as Mirgissa, Buhen, Faras, Serra, Aniba, Kubban, Bigeh and Elephantine (Gardiner 1916; Jaritz 1993).

In fact, the fortresses were built with the aims of controlling the access of Nubian people into Egypt, managing the exploitation of the natural resources located in the eastern and western desert in the vicinity of Nubia, and especially supervising the exchange with Kerma and the African heartland (Adams 1977; Bourriau 1991; Trigger 1976) through a decided advance into the Second Cataract with the effective establishment of a boundary. These objectives appear in the various boundary stelae. The earlier one, Sesostris III's stele of year 8 found in Semna (possibly the location named Heh in the document), specifically indicates that this king established the limit:

In order to prevent all nehesyw passing it in traveling downstream by water or by land with a ship or with all cattle of the nehesyw; except when a nehesy will come in order that trading might be done in Iqen (Mirgissa) on or a commission. Any good thing may be done with them; but without allowing a boat of the nehesyw to pass in traveling downstream by Heh, forever. (Smith 1995:40; see also Adams 1977)

From this time on, the maintenance of the new boundary was considered a legitimizing act of kingship. Direct evidence of this can be found in Sesostris III's stele of year 16, found also at Semna, which indicates: 
Figure. 1. Map of Lower Nubia Egyptian fortresses and look-out posts (Adams 1977: Fig. 27)

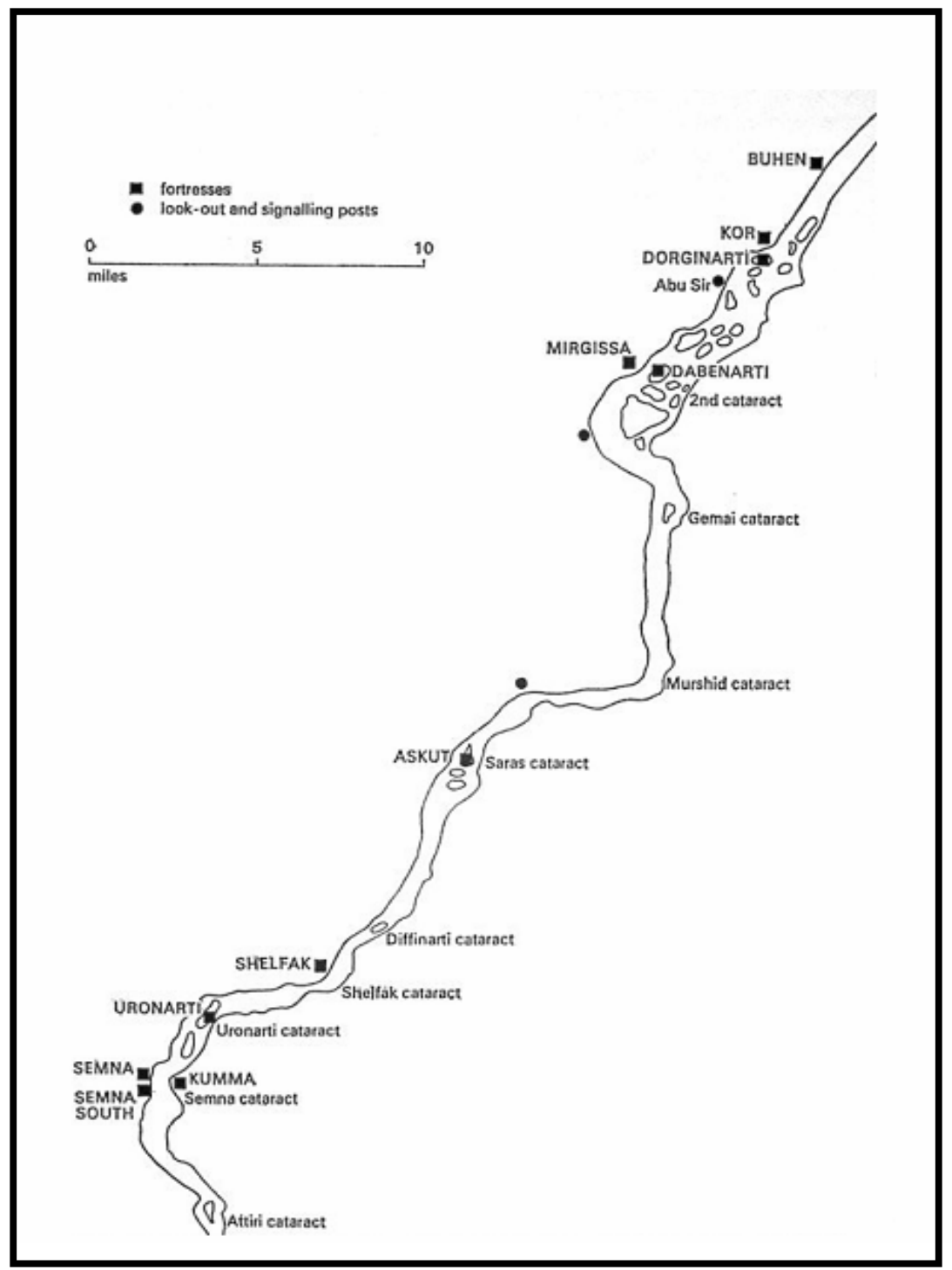

Year 16, third month of winter: the king made his southern boundary at Heh. I have made my boundary further south than my fathers, I have added to what was bequeathed me. (...) As for any son of mine who shall maintain this border which my Majesty has made, he is my son, born to my Majesty. The true son is he who champions his father, who guards the border of his begetter. But he abandons it, who fails to fight for it, he is not my son, he was not born to me. 
Now my majesty has had an image made of my majesty, at this border which my majesty has made, in order that you maintain it, in order that you fight for it. (Lichtheim 1973:119-120)

During the New Kingdom, Sesostris III was worshipped at Semna. His cult was increasingly sustained by Tuthmosis III, who also reopened the aforementioned channel of Sesostris III in the First Cataract and clearly associated himself with the Middle Kingdom king (Spalinger 2006).

Furthermore, the trade in the Lower Nubia region, and therefore its infrastructure, were organized and supervised by Egypt. Egyptian interest in exchange activities is evidenced by the hundreds of seal impressions found at Mirgissa and Uronarti (Gratien 1994), as well as by the inscriptions found in the area of the Second Cataract that make reference to individuals related to navigation and exchange activities (Žába 1974). The exploitation of the local resources is further attested by the presence of workshops at Buhen and granaries and manufacturing areas in almost all of the fortresses, i.e. Kubban, Semna, Kumma, Mirgissa and Askut (Anderson 1999; Kemp 1986). Specifically, it seems that the fortresses at Batn el Hagar were also erected to impede a Kushite advance over Lower Nubia.

Amongst the most notorious evidence regarding the Egyptian administrative control of the fortresses are the Semna Dispatches which dated from the late $12^{\text {th }}$ Dynasty, probably during the reign of Amenemhet (III), the son and successor of Sesostris III. These dispatches contain information about activities at Semna and other fortresses, particularly concerning the interaction with the local Nubians, both nehesyw and medjayw (Smither 1945). The fact that these documents were found at Thebes is an indication that the fortresses' local affairs were directly delivered to the central authorities based out of the Egyptian city (Gratien 2004). In fact, the picture which emerges concerning Sesostris III and Amenemhet III's reigns is one of energetic attempts to tighten the Egyptian hold on Lower Nubian affairs.

Moreover, evidence coming from Uronarti corroborates this fact and suggests that the residence itself was informed of the fortress activities (Smith 1995). Since much of this evidence is dated to $13^{\text {th }}$ Dynasty times, it demonstrates that the control of the Egyptian State over the fortresses did not disappear with the end of the $12^{\text {th }}$ Dynasty.

Additionally, another group of evidence sometimes dismissed by researchers can shed new light on these specific points. The Execration Texts (Koenig 1990; Posener 1940; Sethe 1926) enlist the "enemies" of Egypt - mainly Libyans, Asiatics and Nubians - on figurines or bowls which were interred or destroyed in ritual actions. By means of these ritual actions, enemies were defeated. Of course, and beyond this ritual fact, the Execration Texts provide an enormous amount of information regarding those "enemies" who came from foreign regions.

There are three main lists of Execration Texts, named the Berlin, Brussels, and Mirgissa groups. There is also a smaller group named the Cairo figurines. Fortunately, it is possible to establish a chronological sequence for these groups, although many questions arise when comparing the sources.

It is important to notice that in the earlier group, the Cairo figurines, Wawat was listed between the execrated names in the first place and Kush in the second. But Wawat disappeared from later groups (Berlin, Brussels, and Mirgissa) where the sequence is headed always by Kush (Posener 1958). This is an interesting issue that by itself means little; however, when it is connected with other sources it obtains a different dimension and leads to a possible interpretation 


\section{JOURNAL OF WORLD-SYSTEMS RESEARCH}

connecting the disappearance of Wawat from the late Execration Texts with the status Lower Nubia acquired during the Middle Kingdom.

Finally, another source that can help us delineate the status of Lower Nubia comes from the late Second Intermediate Period. The stele of King Kamose is a document from the late $17^{\text {th }}$ Dynasty. In a very well-known passage, King Kamose states, referring to the situation of the Theban kingdom:

To what end do I know my (own) strength? One chief is in Avaris, another in Kush, and I sit (here) associated with an Asiatic and a Nubian! Each man has his slice in this Egypt and so the land is partitioned with me! (Kamose I) (Redford 1997:13; emphasis added).

During the Second Intermediate Period, an Asiatic kingdom emerged in northeastern Delta. Its main city was Avaris (Tell el Daba) (Bietak 1996; Bietak 1997). At the same time, the Kushites advanced over the Egyptian chain of fortresses located in Lower Nubia. The Egyptians' influence was limited to the area between Elephantine and Kos (Cusae). In fact, recent estimates of the economic situation of the Theban kingdom during the Second Intermediate Period indicate a diminishing level of wealth among its population, which lost its access to former prestige goods (elite funerary items include sarcophagi made of sycamore - an Egyptian wood - and not of the "prestigious" foreign cedar wood) (Yurco 2004:446).

The territories north of Kos were under the dominion of the king of Avaris, and the territories south of Elephantine were under the dominion of the Kushites from Kerma. The quote from Kamose leads one to understand that Lower Nubia once was considered "Egypt." This claim, made by an Egyptian king, adds to the information of the Execration Texts and the boundary stelae of king Sesostris III and is indicative of the possible incorporation of Lower Nubia into the Egyptian State, not only in an administrative, economical, or political sphere, but also in an ideological one.

In addition to the textual evidence, archaeological remains also shed light on this aspect. In fact, a change in the occupation pattern in the Egyptian fortresses can be discerned, as the fortresses shift from rotating military garrisons to permanent Egyptian settlers from the late Middle Kingdom.

If most scholars agree on which goals the Egyptians pursued through the construction of the fortresses, different explanations arise regarding the change in their mode of occupation. Most of these explanations consider only an economic motive.

Years ago, Smith (1976) established this change as taking place at Buhen. He attributed the establishment of the permanent occupation there to a new situation in which the Egyptian State could not confront the steadily increasing costs that resulted from the rotating occupation in the fortress at Buhen during the $13^{\text {th }}$ Dynasty. Among the high costs, he mentioned the practice of sending sick people and dead bodies to Egypt because of the ideological feature related to "die in Kemet," a religious belief expressed in the Tale of Sinuhe (Smith 1976:69).

The change in the mode of occupation was observed also at Mirgissa and Askut. The evidence at Askut showed that the change took place during the late $12^{\text {th }}$ Dynasty, exemplified through new spatial arrangements in the buildings and the establishment of a cult to ancestors (Smith 1995). Smith (1995) came up with an original and cohesive approach to the interrelationship between Egypt and Nubia from the Middle Kingdom to the New Kingdom (ca. 
2050-1050 B.C.), basing his conclusions on an exhaustive analysis of the archaeological remains. He made use of several analytical terms borrowed from other fields of study to explain the Egyptian advance over Lower Nubia, proposing the use of Horvath and Bartel's matrix specifying the differences between "colonialism" (occupation with settlers) and "imperialism" (occupation without settlers). Further, the matrix uses these terms in relation to the strategies of "eradication," "acculturation" and "equilibrium," which create a series of different situations.

Under this matrix, the specific situation in Lower Nubia during the Middle Kingdom is defined as "Equilibrium/Imperialism." This means that it was an "indigenous cultural maintenance with only small imperial presence" (Smith 1995:8-9) through the building of the impressive fortresses system. Local inhabitants (Nubian C-Group) were allowed to remain in the territory, but there was no interrelationship with the Egyptians. Finally, Smith (1995) adds a primarily economic explanation based on the postulates of Alcock's (1989) model which scrutinized the specific mechanisms of "imperial" decision-making by means of an economic approach, namely a strategy to minimize costs by the dominant state.

To this, Smith argues that the local system established in Lower Nubia was inadequate to meet the Egyptian needs, so the Egyptian State created a new system to fit its own necessities: the system of fortresses. But, in order to lower the costs of the imperial infrastructure and to create a more self-sufficient one, the Egyptians created "a system of local finance to help to diminish the costs of wealth extraction" (Smith 1995:80). In this regard, the de-militarization of Lower Nubia and the settlement of Egyptian colonists there took place as a result of the search for a diminution in the costs of maintenance of the Egyptian imperial system, thus making it more "profitable" from the late $12^{\text {th }}$ dynasty on. Smith $(1995,1997)$ argues that the search for greater revenues may have been motivated, in this case, by the increasing influence of the Amorites in the Delta, which would have required a drainage of the state resources towards that area.

This last point is questionable, since by the end of the $12^{\text {th }}$ Dynasty (and even in the early $13^{\text {th }}$ dynasty), when the first permanent settlers arrived to the fortresses, there is not evidence in the Eastern Delta of military actions against the Asiatic settlers located at Tell el Dab a (Bietak 1997); however, it is possible that a reduction in the costs of maintenance of the fortresses system would have allowed those resources to be redirected towards other areas in which the state had interests.

Besides, Smith (2003) states that the Egyptian colonists could have been led by conspicuous consumption, or a need to obtain prestige goods to improve their social status, through their position as mediators in the exchange between the Egyptian State and Kerma. It is possible that the colonists tried to obtain some kind of benefit, since these practices were not strange at all in ancient Near Eastern societies as the Old-Assyrian network of exchange established between Kanish and Assur during the early Second Millennium B.C. demonstrates. But the rules of the exchange - in the Egyptian and in the Old-Assyrian network examples - were established and maintained by the state's administration. Hall (1999) explained that with the emerging of state-based societies, the amount of wealth involved in commerce was increasing. This is the underlying motive that researchers have found supporting the existence of "capitalism" in the ancient world: "it was there. The key, however, is that it was always embedded in a large tributary logic." (Hall 1999:12). As a matter of fact, "conspicuous consumption" could have taken place among the colonists of Lower Nubia, but it was immersed into a dominant state-driven logic of exchanges, based on the obtaining of prestige goods to reproduce social ties. 
As a matter of fact, Egyptians controlled the exchange with Nubia and imposed their rules over it from the late Middle Kingdom on. In this way, there was an asymmetrical relationship between both polities, since specific Egyptian features appeared in Kerma, such as the numerous imported Egyptian seals and sealings (Markowitz 1997; Smith 1998) or the Egyptian pottery from Upper and Lower Egypt found in the Kushite necropolis (Bourriau 2004). In this way, seals, sealings, and pottery found at Kerma demonstrate the strong influence of the core practices on the periphery, and the asymmetrical relationship between one and the other.

Seals and sealings, these important artifacts of ancient exchange, were found in very different contexts at Kerma. Several appeared in the necropolis and were dated to the Classic Kerma period (late $13^{\text {th }}$ dynasty). These objects were considered objects of prestige to the local elites due to their occurrence in funerary contexts (Smith 1998). But recently, Bonnet (2001) announced the finding of "seals fragments and seal impressions, as well as stocks of fine-grained clay ready to be used, it being already worked into small balls, cylinders or rolls and stored in ditches or shallow pits" (Bonnet 2001:31) in an area near the port of the city, clearly with a meaning related to economic activities. These findings were dated earlier than the findings at the cemetery, probably to Middle Kerma - contemporaneous to the Egyptian Middle Kingdom.

Egyptian pottery has been found in the necropolis of Kerma. Recently, Bourriau (2004) demonstrated through marl analysis of the pottery that, firstly, there was a greater amount of pottery originating from Upper and Lower Egypt during the Middle Kerma period than during the Ancient Kerma and, secondly, that until the middle of the $12^{\text {th }}$ dynasty there was a higher proportion of Upper Egyptian pottery, but this reverted to a higher proportion of Lower Egyptian pottery during the middle of the $12^{\text {th }}$ through the $13^{\text {th }}$ dynasty. Finally, by the end of the $13^{\text {th }}$ dynasty, there was only Upper Egyptian pottery in the Kushite cemetery (Bourriau 2004).

In short, Egypt and Kerma participated in an extended network of exchanges during the Middle Kingdom, principally of luxury goods, and they both benefited from this exchange. But during the Middle Kingdom, we possess explicit evidence indicating that the terms of trade were managed and imposed by the Egyptian State and not by the Nubians from Kerma.

Given the core-periphery interactions we have defined in this instance, how can we characterize the status of Lower Nubia during Middle Kingdom Egypt? To be sure, Lower Nubia was geographically an intermediary between Egypt and Upper Nubia, and it acted as a mediator between both areas. However, Lower Nubia did not possess a "mixture" of organizational forms, at least during the Middle Kingdom, like the characterization of a semi-periphery established by Chase-Dunn and Hall (1991). In fact, the organization, administration and control of the Nile area in Lower Nubia were in the hands of the Egyptian State through the control of the fortresses. The Nubian C-group inhabited the area and maintained relationships with the Egyptians, but they controlled neither the river pass nor the core-periphery goods exchange. Consequently, we can argue that the concept of semi-periphery is not an adequate characterization of the status of Lower Nubia, at least as reflected by the $12^{\text {th }}$ and $13^{\text {th }}$ Dynasties' control over the area. Additionally, we can argue that Lower Nubia was a part of the Egyptian State although it did not share the same characteristics the core possessed: there is no evidence that the Egyptian State built chains of interrelated fortresses in the core area itself.

In fact, the primary role of the area, as mentioned above, was to intermediate between Egypt and Upper Nubia. Accordingly, we suggest that in this specific historical situation, a better concept to define Lower Nubia's status would be that of a linking area. This definition emphasizes the condition of Lower Nubia as a mediation area between a core and a periphery, 
thus avoiding the "transitional" bias that the term semi-periphery certainly possesses, and also takes into account that, in fact, Lower Nubia was part of the core and was not politically related to the periphery. In addition, the concept allows us to establish the differences between the linking area, the core, and the periphery.

First, we can discern an asymmetrical relationship between the core and the linking area since many of the practices the core implemented in the linking area were not present in the core itself. In fact, the core operated on the linking area in an asymmetrical way. The particular modes that this asymmetrical relationship took were both through the building of fortresses (and other constructions in the area), the establishment of rotating garrisons in an initial militarized phase, and the establishment of Egyptian colonists once the state dominated the area and the boundary stelae were erected.

Second, there is no evidence of cultural features coming out of the periphery in the fortresses. The Egyptian fortresses were completely Egyptian in architectural features and material culture, and they were managed by the Egyptian State from Thebes. Finally, they constituted a defensive and integrative system given that they had a means of communicating between them.

In fact, from the late $12^{\text {th }}$ dynasty on, the Egyptian core established a trade colony of Egyptians in a recently controlled territory as a way to emphasize that the terms of the exchange were controlled by the core. Furthermore, the existence of a world-system relation between a core and a periphery was strengthened when the fortresses changed from rotating military garrisons to permanent settlers. These colonists acted as delegates of the Egyptian State to carry out exchange activities. This network, headed by the Egyptian terms of trade, was so enduring that when the Egyptian State decentralized during the Second Intermediate Period crisis, these Egyptian colonists worked for the ruler of Kush. When the Egyptian King Kamose recuperated Lower Nubia they returned to the sphere of influence of the Egyptian State (Smith 1995).

Of course, the main goal of the Egyptian advance over Lower Nubia was to control the exchange of prestige goods between Egypt and Kerma. It can be read as clearly and exclusively an economic goal, but what can be discerned from this exchange? Moreover, why did Egyptians need such goods? In the following sections, we shall explore some ideological aspects that can be used to explain the nature of the Egyptian intervention in Lower Nubia and the social and economic changes related to it. As Kemp has clearly stated, "ideology shapes decisions as much as it legitimizes them. Indeed, a useful rule for addressing the question of imperialism might be: first find the ideology" (1997:131). Accordingly, we consider that the economic factors did not act in isolation. The study of other aspects, most notably the state ideology, which was biased by the Egyptian "worldview" (as Weltanschuung), may enrich and complement our understanding of the status of Lower Nubia during the Middle Kingdom.

\section{RECOGNIZING THE EGYPTIAN "WORLDVIEW" IN THE EVIDENCES}

Several difficulties arise as soon as we approach the specific situation of the relationship between Egypt and Nubia during the Middle Kingdom, specifically concerning the archaeological and textual sources and the theoretical frameworks used to explain this interrelationship.

Regarding the material evidence, there are several features to emphasize. The potential for Nubian and Egyptian archaeological remains from Lower Nubia disappeared once the Aswan 


\section{JOURNAL OF WORLD-SYSTEMS RESEARCH}

High Dam was finished. Since then, our material sources have been reduced to archaeological reports of the excavations which took place there more than forty years ago. This material presents several difficulties. On occasion, the excavations were completed in an extremely short time, so control over the material remains was not done cautiously (like in the case of Buhen) (Smith 1976). Sometimes, there is no complete information in the case of a site excavation but only survey reports. In the case of Askut, the complete archaeological work remains unpublished and we have access only to preliminary reports (Badawy 1963, 1964a, b, 1965, 1966) and to the work of Smith (1995), who had access to the unedited papers of Badawy.

The other kind of evidence, ancient Egyptian texts (there is no Nubian written evidence), also has several specific characteristics to be mentioned here. First, many of the texts disappeared forever, especially those written on perishable material like papyrus. Second, the extant texts for the most part refer to the local or central elites' affairs, so the information we have regarding peasants and non-elite people is substantially poor. Finally, while archaeological remains sometimes allow us to establish ethnic differences and similarities (Smith 2003), texts and images are biased by the Egyptian "worldview," a feature difficult to discern only through archaeological vestiges.

Many researchers have pointed out the importance of state ideology in relation to the expansion of the Egyptian State over Nubia as expressed in textual sources, such as Kemp (1997) or Smith (2003). Certainly, these scholars hold different opinions on the role of ideological statements and the "historical rigorousness" textual evidence possesses. Kemp's (1997) explanation relies on the importance of the Egyptian State ideology in extending its borders, giving textual evidence great importance, since texts reflect ideologically biased features that archaeological remains do not. Smith's (2003) conclusion is that textual evidence is embedded with some form of propaganda, since the messages tried to convey to a specific audience or a set of audiences the great wealth and power the Egyptian king possessed. In fact, he mentions the "fictitious" battles of king Ramesses III against Asiatics and Libyans, concluding that their "real" existence was irrelevant to ancient authors. We agree with this last point, but not for the reasons Smith (2003) advocates as the main factor of this lack of "historical rigorousness."

In fact, our concern is not with material culture and textual evidence as a correlate of state ideology, but rather with how state ideology shaped and modified the behavior of the Egyptians in relation to Lower Nubia.

First of all, we need to recognize that our own "worldview" impacts the way we understand and explain political, economic, and religious matters, and that our own worldview sometimes lies at the bottom of our explanations without us being aware of its existence. In fact, in a critical analysis of the ideological basis of the modern world system's theoretical framework, Burch pointed out that liberalism "is a distinctive intellectual tradition (or worldview or ideology)" with many basic characteristics that were at the foundations of world system theory (1995:16). In a similar way, the ancient Egyptians had their own "worldview," which biased much of their textual and iconographical evidence. Nevertheless, the quality of information we can obtain from the sources is significant in many ways.

A point of departure is to reevaluate the way we approach this ancient society, recognizing that the ancient Egyptians shared a worldview of their own. ${ }^{3}$ Of course, this way of

\footnotetext{
${ }^{3}$ In this regard, we shall cite Hobsbawn's reflections: "the discovery of otherness is important. It is important to see, for instance, how different the sense of time was in the pre-industrial period
} 
understanding the relations between men, nature, and the gods was not irrational, but expressed another kind of rationality different from ours, and it possessed many specific characteristics we shall elaborate upon here. Obviously, it does not mean that we have a complete understanding of the ancient Egyptian worldview, but instead that we recognize its existence and try to understand Egyptians through their own lens, to the extent we can. Our knowledge of this field is still small, but further research - mostly from anthropologists - will generate new concepts and categories for better understanding this different worldview.

Nevertheless, we can define some of the characteristics of the Egyptian worldview. First, it was an extremely self-centered worldview, expressed through a particular kind of discourse which was categorized as expression of an "integrative" or "mythical" thinking (Cervelló Autuori 1996; Frankfort 1976). The recognition of this different logic allows us to establish that ancient Egyptians were immersed in what Eliade called the "religious man" thinking. Ancient societies (and modern ones who are not exposed to the ideology of Western culture) conceived of the world as an integrative "sacred" place. Of course, differences exist between diverse societies but they share several aspects.

Second, the recognition of these ideological features does not signify that these societies lived in a peaceful way, which is as unreal as it is impossible. This subject, in fact, is much more complex that the brief reference we shall present here and deserves a profound examination.

The ancient Egyptian society conceived of creation as an act that had taken place in notime or primeval time - the Egyptian "sep-tepy" (the "first time") - so actions which took place in the "real" world are just repetitions of the acts from primeval time (Dunand and Zivie Coche 2004:37) in a cyclic conception of time. The archetypical conformation of kingship is also related to this particular worldview: we have depictions of the powerful Egyptian king smiting his enemies extending over an extremely long period of more than 3,000 years. Of course, this evidence refers to the always triumphant archetype of the Egyptian king-god and cannot necessarily be correlated with "historical" or "real" events. In this way, these are not "fictitious" facts but instead are references to the archetype of the king-god, who has never been defeated. Misunderstandings are generated if we explain Egyptian sources exclusively from our way of understanding time, space, history, and the past.

In that way of thinking, myths occupied a central place. They were the linguistic narrative form which allowed the remembrance and transmission of the archetype and constituted the "only valid revelation of reality" (Eliade 2001:22), while rituals acted as the "sacred actualizing action of the acts of the primeval time" (Cervelló Autuori 1996:20).

In effect, mythical literature derives from the original myth which is unattainable directly (Assman 1977). Each realization of the original myth is different from others but all of the derivations have to remain between the limits of the main signification of the original myth (Campagno 2004c). In addition, as myths and rituals dealt with the sacred world of gods and goddesses, there were secret aspects never revealed to massive audiences but known only to initiates. The oral transmission of myths is a fact that impedes our reconstruction of them and reduces considerably our knowledge of them.

as Edward Thompson and others have tried to show, to discover how different the sense of history was, as Moses Finley has tried to point out in analyzing the classics. This is very important, and until we have discovered this we can't really do very much with the past" (1997:183-184). 


\section{JOURNAL OF WORLD-SYSTEMS RESEARCH}

All these characteristics of the Egyptian "worldview" not only appear in the iconography, but also bias the Egyptian textual discourse. In this way, a worthwhile characteristic of the Egyptian discourse is the "multiplicity of approaches" or "poliocularity" (Frankfort 1976:19-20, ch. 3; Iniesta 1992:78). This particular characteristic refers to the fact that, on occasion, each premise of the discourse is not necessarily related to the next, not recognizing the Aristotelian principle of logical contradiction. In a well-known Egyptian example from the Pyramid Texts, Horus is mentioned as the son of Osiris and the son of Hathor. To our discourse, it would be a paradox since Osiris and Hathor never constituted a hierogamy. But in this kind of discourse, each premise refers to a different aspect of Horus: as the son of Osiris in kingship's terms, and as the son of Hathor from the point of view of his divinity (Cervello Autuori 1996; Frankfort 1976).

As we stated before, the Egyptians conceived their world as the center of the Universe; they tried to keep a delicate equilibrium between the constant action of two forces of opposite and complementary value, named maat or "order" and isfet or "chaos." These two concepts are of key importance to our understanding of the ideological conception of the Egyptian advance over Lower Nubia during the Middle Kingdom.

Maat was the ordered world that resulted from the act of creation out of the primeval chaos. In other words, maat was the created realm or the center of the Universe and was identified with the Egyptian territory - Kemet, the palace and the king. In effect, this "order" was maintained by the Egyptian king-god who had to limit the constant menace of "chaotic" forces. This meant that the Egyptian king had to perform actions that concerned the opposition order/chaos: one was to expand the order's forces; and the other was to limit the advance of chaos' forces.

As the act of creation established a division between those forces, everything that lay outside the ordered core belonged to the realm of chaos.

This dualistic conception of the world translates to the conception of space. As we stated before, Egypt, the center of the universe, was identified with "order." It was where the gods inhabited, a sacred space. While everything outside its limits, such as things, people, and territories which were not clearly defined as "Egyptian," belonged to the realm of chaos and were "chaos bearers." In this self-centered worldview, forces of chaos were constantly trying to defeat maat, and ritual actions performed by the kings and priesthood were attempts to impede its advance. Certainly, this does not mean that sometimes "chaos invaded and defeated maat." Textual sources like The Admonitions of Ipuwer, among others, refer to the effective invasion of the chaos forces into the Egyptian order - criticizing the king for not performing his role properly. Others proclaim the return of the order after a period of dominion of the chaotic forces, as in the Prophecies of Neferty.

Of course, we are far from those explanations that suggest only propagandistic reasons (in the modern sense of the concept) for the ruling class in the textual and iconographical sources. In the same way, we do not agree with explanations based on some kind of elite class consciousness that allowed for appropriations and manipulations of religion as a means of obtaining power, maintaining political ties, or acquiring class prerogatives.

Taking into account all of these considerations, we can attempt to delineate the ideological bias that existed in the relationship between the Egyptian State and Lower Nubia during the Middle Kingdom. 


\section{TRADE IN LUXURIES}

Scholars tend to agree that the origin of the contacts between the diverse regions of the ancient Near East can be attributed to the demand of luxuries by the local elites (e.g., Sherratt and Sherratt 1991, 1998). This has been shown, for example, in the case of Egypt, where in pre-state and state times, elites allegedly developed relationships with other regions with the aim of providing themselves with luxuries (Campagno 2004a): gold, ebony, ivory, incense, electrum, malachite, aromatic plants, and animal skins that came from Upper Nubia and beyond (Shinnie 1991). In this regard, we can assume an economic goal underlined by ideological features.

In point of fact, prestige goods possess certain qualities: high demand (most notably, from the upper-ranking social strata), low supply (a relatively high value compared with the small amounts transported), and circulation networks over long distances (Sherratt and Sherratt 1991).

However, if one looks to define what a luxury good is and what is not, one realizes that the limit between both categories is of a rather diffuse character. For example, there are certain raw materials and manufactured products that can be included within the category of luxury goods, but there are other raw materials and manufactured products that cannot. What factors played a part in the qualification of a good as a luxury? In ancient societies, luxury goods provided the individual that carried, accumulated, or gave them with certain socially established qualities that differentiated the individual from the rest of the society, that is to say prestige (Campagno 1998; Clastres 1981). Peregrine (1999) - following Habermas's hypothesis that a crisis in a socio-cultural system, a "legitimation crisis" is a more likely source of political collapse than an environmental calamity or a crisis in the subsistence economy - stated that prestige goods play a key role in a "prestige economy" where social reproduction is clearly linked to those goods (Peregrine 1999:39). We emphasize this statement, given that in ancient Egyptian society prestige goods played a key role in the reproduction of social ties in and between social strata. As Peregrine points out: "By guiding this system, the elites effectively ensure their own status, but they also provide opportunities for status enhancement to their followers, the non-elites in the system. The non-elites, in return, provide loyalty to the elites" (1999:40). That is to say, prestige goods produced and reproduced inter-social strata practices. In this way, the capacity to obtain luxury items (to accumulate and distribute them), made possible the institution of certain attributes that further developed internal social hierarchies. In other words, these kinds of goods originated and complemented the process of conformation and maintenance of the ancient elites' infrastructures. These strategies might appear in social relationships such as patronage or gift giving. In societies where there are clear social differences, but where legally coercive institutions do not exist, the giving of these goods as "gifts" form actual contractual forces between the giver and the receiver (Graziano 1975:25-27; see also Schneider 1977).

In addition to these qualities, luxury goods possessed a socially established value of another kind. Here we can mention their sacred quality, their power to cure, their physical properties (for example, certain colors or shapes), their character of being "gifts of the king," or their use during rituals as "sacra." As Simmel (1978) pointed out, a good's value does not constitute an inherent property of the object, but rather is a property attributed to them by subjects. To Mauss, luxuries were imbued with a "spiritual matter (...) part of the nature and substance of oneself" (1954:10). Consequently, luxuries had a social meaning and underwent transformations in their values, because they were indicative of the community's relationships at 


\section{JOURNAL OF WORLD-SYSTEMS RESEARCH}

both an external and internal level. This socially shared value often had a greater incidence than the scarcity of the goods in the sector that demanded them (Appadurai 2003; Simmel 1978).

In summary, the main characteristic of luxury goods is the social value that a certain society attributes to them. This explains why some of these goods crossed over long distances to arrive at their destination, which probably initiated the long-distance exchange networks.

What kind of luxury items did the Egyptians obtain from Nubia? Gold was an extremely important precious metal to the Egyptians due to its symbolic resemblance of the flesh of the gods which were made from it, as related to the solar god Re. But, beyond its symbolic bias, this precious metal - like silver - had a different status than others since it was used in pre-monetary economies as a patron of exchange. The Egyptian State probably had to obtain silver through exchange with the city-ports of Syria, given that the source of that precious mineral was in Anatolia, as the Old Assyrian trade-system evidence clearly proves.

Besides gold, Egyptians imported ebony, ivory, myrrh, incense, and panther and leopard skins from Nubia. What products did Egypt send south? There is scant evidence of the products sent by Egypt. These could include items which degrade quickly, like unguents, oils, perfumes, and textiles. Egyptian pottery was found at Kerma, and it shows a patron of exchange that suffered changes over time, as we stated before.

In short, control over Lower Nubia can be explained not only by pure economic necessity on the part of the Egyptian State to assure the arrival of certain luxury goods; but also, and perhaps more importantly, this arrival was compelled by questions of ideological character that had much to do with the role played by luxuries in the conformation of the Egyptian society.

\section{THE CONCEPT OF BOUNDARY TO THE ANCIENT EGYPTIANS}

For ancient Egyptians, the border was neither a stable element nor did it have the connotations by which we define a "border" today. As Quirke pointed out, we can differentiate between the concepts of "border" and "boundary" or limit. "Border" can be interpreted as "an indefinite zone to a state entity" while "boundary" (or "limit") can be understood as a "line which demarcates the state sovereignty" (1989:264).

In the idea of boundary, there are elements that have a lot to do with the particular conception of the world that the Egyptians shared. As we have stated before, Egypt was a territory ruled by a king-god and governed by maat ("order"), which extended over an area that originally included the Nile River's south-north section between Elephantine and the Mediterranean Sea. Everything outside of such limits, exceeding the territorial materialization of the concept of Kemet, was considered to be a land of chaos, and its inhabitants were chaos bearers. This can be seen in the case of the Libyans (to the West), the Asiatics (to the East), and the Nubians (to the South), neighboring peoples that were considered the enemies par excellence; they were characterized in texts and represented as such in the iconography and, thus, they became objects of the "ritual death of the enemy." In addition, it is worthwhile to focus attention on the necessity for the Egyptians "to die in Kemet," the ambit of the order, as is expressed clearly in the Tale of Sinuhe when he returns to Egypt to die (Sinuhe B197-199) (Blackman 1932:32; Lichtheim 1973:229-230).

Egyptians utilized two terms to refer to the concept of frontier: tash and djer-a. The idea of tash was intrinsically related to the concept of the limit that the king could impose and modify 
in historically precise situations. On the other hand, djer- $a$ was a term related to the limits of the cosmic world. As Hornung puts it:

Djer-a refers to the absolute, unalterable limit that is part of the cosmic structure itself... The Egyptians used tash for structuring devices and measures of all kinds. The term might refer to the boundary of a field or piece of property, or to district or state borders. (1992:73)

The king was the ruler and god responsible for order (maat) and, as such, "he who extends the boundaries (tashw)" of maat (e.g., the Hymns to Sesostris III) (Flammini and Gestoso 2003:29). The political boundaries of the state - both those established between the nomes and those between the state and the neighboring areas - fluctuated. Since it was the king-god who instituted these limits, it is very difficult to establish a sharp distinction between the concept of a political boundary established by the king and the boundary "of the ambit of the order (maat)" established by the god. Both elements together composed the concept tash.

This opposition sheds new light on the Egyptian conception of the Nubian "boundary." In the Egyptian topos, there is an opposition between the Egyptians and foreigners: the latter are bearers of chaos, and therefore opposed to maat; accordingly the king is forced to fight Egypt's enemies (Assman 1990; Loprieno 1988).

Regarding this point, Smith (2003) argues that the C-Group people exerted a kind of resistance to the Egyptian presence in Lower Nubia by avoiding any kind of contact, but other researchers have pointed out that there was some kind of exchange between them given the appearance of Egyptian objects as luxury items related to prestige in many tombs of the C-Group (Anderson 1999). Furthermore, research on archaeological material in Lower Nubia reveals that the Nubian C-Group people and the Egyptians coexisted peacefully in Areika, a Nubian site which presented features of both societies (Wegner 1995).

The relationship between the description of foreigners in the ancient Egyptian texts and the material remains related to them would appear to be paradoxical. But, in fact, both aspects concern different spheres of interpretation. As the first suggests an ideological explanation of the position of Egypt as center of the Universe and the land of cosmological "order," the opposite of "chaos," the second refers to daily life situations. Given that, we can ask ourselves if a land belonging to the "chaos realm," as did Lower Nubia, could be incorporated into the king-god's dominion.

Hornung named the permanent expansion of Egypt and Egyptian features - including the state's limits - as the principle of the "extension of the existing" (1992:82; see also Kemp 1985). Rowlands (1987) also refers to this specific feature, in terms related to the continuum between the "lands of order" and the "lands of chaos." The latter were conceived of as a failed cosmos, "one not yet realized but one that could be eventually" (1987:9). In this regard, space is a variable wherein territorial disruptions, like mountains, deserts, or seas, could act as natural borders between the lands of "order" and "chaos." In the same way, continuations in certain territorial features allow that a territory could be ideologically incorporated in an easier way. This could be the case between Egypt and Lower Nubia, who were linked by the Nile (Adams 1977). This fact would have allowed a different ideological conception of the foreign lands that extended to the south, and this particular situation has no correlation in Syria or Palestine who were clearly 


\section{JOURNAL OF WORLD-SYSTEMS RESEARCH}

separated from Egypt by the Mediterranean Sea and the desert of Sinai. ${ }^{4}$ The construction of Egyptian buildings, like fortresses, temporary palaces, and temples, could have been a way of transforming a land of chaos into a land of order. In fact, although we have no explicit references to this specific issue, it is possible to think that the Egyptian idea of "expanding the existing order" can effectively be correlated with the economic and political expansion of the Egyptian core over Lower Nubia.

In this way, the installation of boundary stelae at Semna could imply that the section of the Nile that extended between the First Cataract and Semna was included in the Egyptian State (Vandersleyen 1971) as the Execration Texts and the stele of King Kamose confirm. Thus, through the establishment of the boundary stelae and the building of Egyptian structures, Lower Nubia would have been integrated into the order of the Egyptian world, a zone gained out of chaos and incorporated into the dominions of the king-god.

This is why the de-militarization and change in the mode of occupation of the fortresses can not be attributed only to a purported search for a reduction in the costs of the "imperial" infrastructure through the generation of economic self-sufficiency.

In other words, we are suggesting another explanation, in addition to the exclusively economic one. The effective pacification and incorporation of Lower Nubia into the Egyptian "order," once the boundary stelae had been erected, meant that the war against the chaos had been temporarily won, at least in Lower Nubia. It is possible that this was the underlying reason behind the decision - after the reign of Sesostris III and the establishment of the boundary stelae - to not construct new fortresses in the area and to maintain the border that the king had established.

Our evidence, then, clearly indicates a correlation between state ideology and social practice. This new situation of inclusion of Lower Nubia into the Egyptian State would have led the Egyptians to use a different mode of occupation in the area. As we stated before, the tightening of the Egyptian grasp over Lower Nubia is illuminated by the archaeological research and textual data. The change in the mode of occupation consisted principally in the settlement of Egyptian colonists in the area, as the foundation of cultic places to worship ancestors and other architectural changes in the original plan of the fortresses demonstrate. These changes were dated by the end of the $12^{\text {th }}$ Dynasty. Clearly, these new customs are a consequence of the inclusion into the Egyptian "order": it was no longer necessary to return to Egypt to die, because in Lower Nubia one was already in Egyptian territory, within the boundaries of the state, inside the dominions of the order established and guaranteed by the king-god. In fact, political and ideological factors are at least as important as economics in structuring political interaction (Edens 1992).

A key argument in support of our idea of the Egyptian advance on Lower Nubia would be to establish that this specific situation was repeated in Egyptian history. In fact, in later historical situations like that of the New Kingdom, Egyptian kings also erected boundary stelae (i.e., Tuthmosis I and III at Kurgus, although they do not have the legitimizing bias the Sesostris III's boundary stela has) (Arkell 1950; Davies 2003). Egyptian kings built huge temples and administrative structures in Nubia as far as the Fourth Cataract, but we can not infer directly from the sources the existence of a "greater" Egypt. Syrian, Palestinian, and Nubian territories

${ }^{4}$ On the relationship between topography and the conception of a sacred cosmos, see Eliade (1998). 
supported an administrative, political, and economic advance of the Egyptian reunited core, but we can figure that those territories also were seen as dominions of the king-god obtained by his own right to "extend the boundaries of the ordered world." A close approach to the Egyptian ideological statements could lead us to evaluate different hypotheses. In effect, the Egyptian advance over Nubia - and of course, over the Levant - during the New Kingdom was of a different kind that that of the Middle Kingdom (Kemp 1997). As a consideration of the situation during the New Kingdom exceeds the goals of this paper, we shall only present a brief possible explanation that would deserve a more extensive approach.

We can hypothesize that between the Middle and the New Kingdom an extremely profound state crisis took place, namely the Second Intermediate Period. During this difficult period, the Egyptian State lost its centrality to, precisely, the hands of foreigners or "chaos bearers." In ideological terms, chaos forces defeated order, reducing the "ordered world" to the small region between Kos and Elephantine, the Theban kingdom. In fact, the Egyptian kings who reigned during the crisis were unable to impede this situation. The northeastern axis of the Nile came under Asiatic rule and Lower Nubia fell under the dominion of the ruler of Kush. In addition, we have information regarding the close connection between the Asiatics and Nubians, which allied to defeat the Egyptian king of the Theban kingdom (Second Stela of Kamose) (Habachi 1972). Given this, it is possible to argue that the historical, ideological, and social situations were extremely different in the Middle Kingdom from those of the New Kingdom, and that the Second Intermediate Period crisis imprinted its consequences upon the Egyptian consideration of foreigners and foreign regions.

\section{CONCLUSIONS}

In this paper, we have argued that the ideology of the Egyptian State should have the same level of analytical importance as the purely economic considerations of the Egyptian advance over Lower Nubia, since these later aspects were biased by the Egyptian worldview. This process is one of expansion of state ideology, namely, an order that legitimates occupation by reference to an overarching identity.

During the Middle Kingdom, the Egyptian State advanced into Lower Nubia - that section of the Nile that extends between the First Cataract and the Batn el Hagar - and founded a chain of fortresses with the purpose of controlling the flow of goods towards Egypt, controlling the entrance of people, and exploiting the natural resources of the region. The Egyptian State maintained control in the area until the very late $13^{\text {th }}$ Dynasty. A change in the mode of occupation in the Egyptian fortresses can be discerned by the end of the $12^{\text {th }}$ Dynasty, from rotating to permanent. This feature was ideologically related to the incorporation of the territory into the Egyptian State, evidenced by the installation of boundary stelae in the vicinity of Semna by Sesostris III. Further, it explains the subsequent de-militarization of Lower Nubia and the settlement of Egyptian colonists in the territory. We have characterized the status of Lower Nubia as a linking area between a core (Egypt) and a periphery (Kerma). This categorization is a model generated to understand the role developed by the area during the Middle Kingdom Egypt.

The development sketched above is, of course, somewhat simplistic, but it shows that the Egyptian State's policy abroad should be seen not only from a purely economic point of view. 
The state's ideology played an important part in the new social order imposed upon this linking area.

\section{REFERENCES}

Adams, William Y. 1977. Nubia: Corridor to Africa. Princeton, NJ: Princeton University Press.

Alcock, Susan E. 1989. "Archaeology and Imperialism: Roman Expansion and the Greek City." Journal of Mediterranean Archaeology 2:87-135.

Algaze, Guillermo. 1993. The Uruk World System: The Dynamics of Expansion of Early Mesopotamian Civilization. Chicago, IL: The University of Chicago Press.

2001. "The Prehistory of Imperialism: The Case of Uruk Period Mesopotamia." Pp. 27-83 in Uruk, Mesopotamia \& its Neighbors: Cross-Cultural Interactions in the Era of State Formation, edited by M. S. Rothman. Santa Fe, NM: School of American Research Advanced Seminar Series.

Anderson, Wendy R. M. 1999. The Significance of Middle Nubian C-Group Mortuary Variability, ca. 2200 B.C. to ca. 1500 B.C. Ph.D. dissertation. McGill University, Montreal, Quebec, Canada.

Appadurai, Arjun. (ed.). 2003. The Social Life of Things: Commodities in Cultural Perspective, $2 d$ ed. Cambridge, United Kingdom: Cambridge University Press.

Arkell, Anthony J. 1950. "Varia Sudanica." Journal of Egyptian Archaeology 36:24-42.

Assmann, Jan. 1977. "Die Verborgenheit des Mythos in Ägypten.” Göttinger Miszellen 25:7-43. . 1990. Ma'at: Gerechtigkeit und Unsterblichkeit im Alten Ägypten. München, Germany: Beck.

Badawy, Alexander. 1963. "Excavation Under the Threat of the High Dam: The Ancient Egyptian Island Fortress of Askut in the Sudan, Between the Second and Third Cataracts." Illustrated London News, June 22, pp. 964-966.

. 1964a. "An Egyptian Fortress in the Belly of the Rock: Further Excavations and Discoveries in the Sudanese Island of Askut." Illustrated London News, July 16, pp. 8688.

. 1964b. "Preliminary Report on the Excavations by the University of California at Askut." Kush XII, pp. 47-53.

. 1965. "Askut: A Middle Kingdom Fortress in Nubia." Archaeology 18:124-131.

. 1966. "Archaeological Problems relating to the Egyptian Fortress at Askut." Journal of the American Research Center in Egypt V:23-27.

Bietak, Manfred. 1996. Avaris: The Capital of the Hyksos. New Excavations Results. London, United Kingdom: British Museum.

. 1997. "The Center of Hyksos Rule: Avaris (Tell el Dabca)." Pp. 87-139 in The Hyksos: New Historical and Archaeological Perspectives, edited by E. Oren, Philadelphia, PA: University of Pennsylvania Museum.

Blackman, Alyward M. 1932. Middle-Egyptian Stories. Vol. I, Bibliotheca Aegyptiaca II. Brussels, Belgium: Foundation Egyptologique Reine Elisabeth.

Bonnet, Charles. 1986. Kerma, Territoire et Métropole: Quatre leçons au Còllege de France. Cairo, Egypt: Bibliothèque Générale de l'Institut Français d'Archéologie Orientale du Caire IX. 
2000. Edifices et Rites Funéraires à Kerma. Paris, France: Errance.

2001. "Les Empreintes de Sceaux et les Sceaux de Kerma: Localization des Découvertes." Cahier de Recherches de l'Institut de Papyrologie et Égyptologie de Lille 22:27-31.

Bourriau, Janine. 1991. "Relations between Egypt and Kerma during the Middle and New Kingdoms." Pp. 129-144 in Egypt and Africa: Nubia from Prehistory to Islam, edited by W. V. Davies. London, United Kingdom: British Museum Press and the Egypt Exploration Society.

. 2004. "Egyptian Pottery found in Kerma Ancien, Kerma Moyen and Kerma Classique Graves at Kerma." Pp. 3-13 in Nubian Studies 1998: Proceedings of the Ninth Conference of the International Society of Nubian Studies, August 21-26, 1998, Boston, Massachusetts, edited by T. Kendall. Boston, MA: Department of African-American Studies, Northeastern University.

Burch, Kurt. 1995. "Invigorating World-System Theory as Critical Theory: Exploring Philosophical Foundations and Postpositivist Contributions." Journal of World-Systems Research 1:1-104.

Campagno, Marcelo. 1998. Surgimiento del Estado en Egipto: Cambios y Continuidades en lo Ideológico. Colección Estudios, Nueva Serie 6. Buenos Aires, Argentina: Universidad de Buenos Aires.

2002. De los Jefes-Parientes a los Reyes-Dioses: Surgimiento y Consolidación del Estado en el Antiguo Egipto. Aula Ægyptiaca Studia 3. Barcelona, Spain: Aula Ægyptiaca.

. 2004a. "Antiguos Contactos Entre Centros y Periferias: Un Estudio Introductorio." Pp. 924 in Antiguos Contactos: Relaciones de Intercambio Entre Egipto y sus Periferias, edited by A. Daneri Rodrigo and M. Campagno. Buenos Aires, Argentina: Instituto de Historia Antigua Oriental, Universidad de Buenos Aires.

. 2004b. "Sobre Bienes de Prestigio, Orden y Caos: El Estado Egipcio y sus Periferias Durante el Período Dinástico Temprano (ca. 3000-2700 a.C.)." Pp. 41-69 in Antiguos Contactos: Relaciones de Intercambio Entre Egipto y sus Periferias, edited by A. Daneri Rodrigo and M. Campagno. Buenos Aires, Argentina: Instituto de Historia Antigua Oriental, Universidad de Buenos Aires.

2004c. Una Lectura de la Contienda entre Horus y Seth. Buenos Aires, Argentina: Ediciones del Signo and Universidad de Buenos Aires.

Cervelló Autuori, Josep. 1996. Egipto y África: Origen de la Civilización y la Monarquía Faraónicas en su Contexto Africano. Sabadell, Spain: Editorial Ausa.

Chase-Dunn, Chistopher and Thomas Hall. 1991. "Conceptualizing Core/Periphery Hierarchies for Comparative Study." Pp. 5-44 in Core/Periphery Relations in Precapitalist Worlds, edited by C. Chase-Dunn and T. Hall. 2 d ed. Boulder, CO: Westview Press.

Clastres, Pierre. 1981. Investigaciones en Antropología Política. Barcelona, Spain: Gedisa.

Davies, William Vivian. 2003. "La Frontière Méridionale de l'Empire: Les Égyptiens à Kurgus." Bulletin de la Société Française d'Egyptologie 157:23-37.

Dunand, Françoise and Christiane Zivie-Coche. 2004. Gods and Men in Egypt: 3000 BCE to 395 $C E$. Ithaca, NY: Cornell University Press.

Edens, Christopher. 1992. "The Dynamics of Trade in the Ancient Mesopotamian WorldSystem." American Anthropologist 94:118-139.

Eliade, Mircea. 1998. Lo Sagrado y lo Profano. 2d ed. Barcelona, Spain: Paidós. . 2001. Mitos, Sueños y Misterios. 2d ed. Barcelona, Spain: Kairós. 
Emery, Walter. 1965. Egypt in Nubia. London, United Kingdom: Hutchinson.

Flammini, Roxana and Graciela Gestoso. 2003. "Los Himnos a Sesostris III." Aegyptus Antiqua $11: 21-26$.

Frankfort, Henri. 1976. Reyes y Dioses: Estudio de la Religión del Oriente Próximo en la Antigüedad en Tanto que Integración de la Sociedad y la Naturaleza. 2d ed. Madrid, Spain: Revista de Occidente.

Gardiner, Alan. 1916. "An Ancient List of the Fortresses of Nubia." Journal of Egyptian Archaeology 3:184-192.

Gratien, Brigitte. 1978. Les Cultures Kerma: Essai de Classification. Lille, France: Université de Lille III.

1994. "Départements et Institutions dans les Forteresses Nubiennes au Moyen Empire." Pp. 185-197 in Hommages à Jean Leclant, vol. 2, Nubie, Soudan, Ethiopie. Cairo, Egypt: Institut Français de Archéologie Orientale.

. 2004. "From Egypt to Kush: Administrative Practices and Movements of Goods During the Middle Kingdom and the Second Intermediate Period." Pp. 74-82 in Nubian Studies 1998: Proceedings of the Ninth Conference of the International Society of Nubian Studies, August 21-26, 1998, Boston, Massachusetts, edited by T. Kendall. Boston, MA. Department of African-American Studies, Northeastern University.

Graziano, Luigi. 1975. A Conceptual Framework for the Study of Clientelism. (Western Societies Program, Occasional Papers No. 2). New York: Cornell University.

Habachi, Labib. 1972. The Second Stela of Kamose. Vol. 8, Abhandlungen des Deutschen Archäelogischen Instituts Kairo, Agyptologische Reihe. Glückstadt, Germany: J.J. Augustin.

Hall, Thomas D. 1999. "World-Systems and Evolution: An Appraisal." Pp. 5-23 in WorldSystems Theory in Practice: Leadership, Production, and Exchange, edited by P. N. Kardulias. New York: Rowman \& Littlefield.

Hobsbawm, Eric. 1997. On History. New York: The New Press.

Hornung, Erik. 1992. Idea Into Image. New York: Timken Publishers.

Iniesta, Ferrán. 1992. El Planeta Negro: Aproximación Histórica a las Culturas Africanas. Madrid, Spain: Cyan.

Jaritz, Horst. 1993. "The Investigation of the Ancient Wall Extending from Aswan to Philae, with a Contribution on the Pottery from the Watch-tower at Tell Asmar by M. Rodziewicz." Mitteilungen des Deutches Agyptologischen Instituts, abt. Kairo 49:107-132.

Kardulias, Paul N. 1996. "Multiple Levels in the Aegean Bronze Age World-System." Journal of World-Systems Research 11:1-35.

Kemp, Barry J. 1978. "Imperialism in New Kingdom Egypt (c. 1575-1087 BC)." Pp. 283-297 in Imperialism in the Ancient World, edited by P. D. A. Garnsey and C. R. Whittaker. Cambridge, United Kingdom: Cambridge University Press.

. 1985. "El Imperio Antiguo, el Imperio Medio y el Segundo Período Intermedio." Pp. 98230 in Historia del Egipto Antiguo, edited by B.G. Trigger, B. J. Kemp, D. O’Connor, and A. B. Lloyd. 2d ed. Barcelona, Spain: Grijalbo.

1986. "Large Middle Kingdom Granary Buildings (and the Archaeology of Administration)." Zeitschrift für Ägyptische Sprache und Altertumskunde 113:120-136. 
. 1997. "Why Empires Rise?" Review of Askut in Nubia: The Economics and Ideology of Egyptian Imperialism in the Second Millennium BC, by Stuart Tyson Smith. Cambridge Archaeological Journal 7:125-131.

Koenig, Yvan. 1990. “Les Textes d'Envoûtement de Mirgissa.” Revue d'Egyptologie 41:101-125.

Kohl, Philip. 1987. "The Ancient Economy, Transferable Technologies and the Bronze Age World-System: a View from the Northeastern Frontier of the Ancient Near East." Pp. 1324 in Centre and Periphery in the Ancient World, edited by M. Rowlands, M. Larsen, and K. Kristiansen. Cambridge, United Kingdom: Cambridge University Press.

Lacovara, Peter. 1997. "Egypt and Nubia during the Second Intermediate Period." Pp. 69-83 in The Hyksos: New Historical and Archaeological Perspectives, edited by E. Oren. Philadelphia, PA: University of Pennsylvania Museum.

Lichtheim, Miriam. 1973. Ancient Egyptian Literature: a Book of Readings. Berkeley, CA: University of California Press.

Loprieno, Antonio. 1988. Topos und Mimesis (Ägyptologische Abhandlungen). Wiesbaden, Germany: Harrassowitz.

Markowitz, Yvonne. 1997. "Appendix: the Seals from Kerma." Pp. 379-414 in The Hyksos: New Historical and Archaeological Perspectives, edited by E. Oren. Philadelphia, PA: University of Pennsylvania Museum.

Mauss, Marcel. 1954. The Gift. Forms and Functions of Exchange in Archaic Societie., 2d ed. London, United Kingdom: Cohen \& West.

Mills, Anthony J. 1967-68. "The Archaeological Survey from Gemai to Dal: Preliminary Report on the Season 1964-65." Kush XIV:200-210.

Morkot, Robert G. 2000. The Black Pharaohs: Egypt's Nubian Rulers. London, United Kingdom: The Rubicon Press.

O'Connor, David. 1991. "Early States Along the Nubian Nile." Pp. 145-165 in Egypt and Africa: Nubia from Prehistory to Islam, edited by W. V. Davies. London, United Kingdom: British Museum Press and the Egypt Exploration Society.

1993. Ancient Nubia: Egypt's Rival in Africa. Philadelphia, PA: University of Pennsylvania.

Peregrine, Peter N. 1999. "Legitimation Crises in Prehistoric Worlds." Pp. 37-52 in WorldSystems Theory in Practice: Leadership, Production, and Exchange, edited by P. N. Kardulias. New York: Rowman \& Littlefield.

Posener, Georges. 1940. Princes et Pays d'Asie et de Nubia: Textes Hiératiques sur des Figurines d'envoûtement du Moyen Empire. Brussels, Belgium: Fondation Égyptologique Reine Elisabeth.

. 1958. "Pour une Localization du Pays Koush au Moyen Empire." Kush VI:39-68.

Quirke, Stephen. 1989. "Frontier or Border? The Northeastern Delta in Middle Kingdom Texts." Pp. 261-274 in Proceedings of the Colloquium The Archaeology: Geography and History of the Egyptian Delta in Pharaonic Times, Wadham College, 29-31 August, 1988, edited by A. Nibbi. Oxford, United Kingdom: Discussions in Egyptology Publications.

. 1990. The Administration of Egypt in the Late Middle Kingdom: The Hieratic Documents. New Malden, Surrey: SIA Publishing.

Redford, Donald B. 1997. "Textual Sources for the Hyksos Period.” Pp. 1-44 in The Hyksos: New Historical and Archaeological Perspectives, edited by E. Oren. Philadelphia, PA: University of Pennsylvania Museum. 
Reisner, George A. 1923a. Excavations at Kerma I-III. Harvard African Series, Vol. 5. Cambrige, MA: Harvard University Press.

. 1923b. Excavations at Kerma IV-V. Harvard African Series, Vol. 6. Cambridge, MA: Harvard University Press.

Rothman, Mitchell S. 2001. "The Local and the Regional." Pp. 3-26 in Uruk, Mesopotamia \& Its Neighbors: Cross Cultural Interaction in the Era of State Formation, edited by M. S. Rothman. Santa Fe, NM: School of American Research Press.

Rowlands, Michael. 1987. "Centre and Periphery: A Review of a Concept." Pp. 1-11 in Centre and Periphery in the Ancient World, edited by M. Rowlands, M. Larsen, and K. Kristiansen. Cambridge, United Kingdom: Cambridge University Press.

Sadr, Karim. 1987. "The Territorial Expanse of the Pan-Grave Culture." Archéologie du Nil Moyen 2:265-291.

. 1990. "The Medjay in Southern Atbai." Archéologie du Nil Moyen 4:63-86.

Sethe, Kurt. 1926. Die Achtung Feindlicher Fursten, Volker und Dinge auf Altagyptischen Tongefassscherben des Mittleren Reiches. Berlin, Germany: Akademie der Wissenchaften.

Schneider, Jane. 1977. "Was There a Pre-capitalist World-System?" Peasant Studies 6:1:20-29.

Schneider, Thomas. 2003. Ausländer in Ägypten, Wahrend des Mittleren Reiches und der Hyksoszeit. Vol 2, Die Ausländische Bevölkerung. Wiesbaden, Germany: Harrassowitz.

Sherratt, Andrew and Susan Sherratt. 1991. "From Luxuries to Commodities: The Nature of Mediterranean Bronze Age Trading Systems." Pp. 351-386 in Bronze Age Trade in the Mediterranean, edited by N. H. Gale. Goteborg, Sweden: Studies in Mediterranean Archaeology.

1998. "Small Worlds: Interaction and Identity in the Ancient Mediterranean." Pp. 329-342 in The Aegean and the Orient in the Second Millennium, edited by E. Cline and D. Harris-Cline. Liège, Belgium: AEGAEUM.

Shinnie, Peter L. 1991. "Trade Routes of the Ancient Soudan." Pp. 49-53 in Egypt and Africa. Nubia from Prehistory to Islam, edited by W. V. Davies. London, United Kingdom: British Museum Press and Egypt Exploration Society.

Simmel, Georg. 1978. The Philosophy of Money. 2d ed. London, United Kingdom: Routledge.

Smith, Harry S. 1976. The Fortress of Buhen: The Inscriptions, $48^{\text {th }}$ Excavation Memoir. With assistance from Walter Emery, Barry J. Kemp, Geoffrey T. Martin and David O'Connor. London, United Kingdom: Egypt Exploration Society.

Smith, Stuart Tyson. 1995. Askut in Nubia. London, United Kingdom: Kegan Paul International. . 1997. "State and Empire in the Middle and New Kingdoms." Pp. 66-89 in Anthropology and Egyptology: A Developing Dialogue, edited by J. Lustig. Sheffield, United Kingdom: Sheffield Academic Press.

. 1998. "The Transmission of an Administrative Sealing System from Lower Nubia to Kerma." Cahiers de Recherches de l'Institut de Papyrologie et Égyptologie de Lille 19:219-230.

. 2003. Wretched Kush. Ethnic Identities and Boundaries in Egypt's Nubian Empire. London, United Kingdom: Routledge.

Smither, Paul. 1945. "The Semnah Dispatches.” Journal of Egyptian Archaeology 31:3-10. 
Spalinger, Anthony. 2006. "Covetous Eyes South: The Background to Egypt's Domination of Nubia by the Reign of Tuthmosis III." Pp. 344-369 in Thutmose III. A New Biography, edited by E. H. Cline and D. O'Connor. Ann Arbor, MI: University of Michigan Press.

Stein, Gil. 1999. Rethinking World-Systems: Diasporas, Colonies, and Interaction in Uruk Mesopotamia. Tucson, AZ: University of Arizona Press.

Trigger, Bruce. 1976. Nubia Under the Pharaohs. London, United Kingdom: Thames and Hudson.

Vandersleyen, Claude. 1971. Les Guerres d'Amosis, Fondateur de la XVIIIe: Dynastie. Brussels, Belgium: Monographies Reine Elisabeth 1. 1995. L'Egypte et la Vallée du Nil. Vol II, De la Fin de l'Ancien Empire à la Fin du Nouvel Empire. Paris, France: Nouvelle Clio.

Wallerstein, Immanuel. 1974. The Modern World-System: Capitalist Agriculture and the Origins of the European World Economy in the Sixteenth Century. New York: Academic Press.

Wegner, Josef. 1995. "Regional Control in Middle Kingdom Lower Nubia: the Function and History of the Site of Areika." Journal of the American Research Center in Egypt XXXII:127-160.

Wolf, Eric. 1982. Europe and the People without History. Berkeley, CA: University of California Press.

Yurco, Frank. 2004. "Kerma, the Hyksos, the Medja, and Dynasty 17." Pp. 446-448 in Nubian Studies 1998: Proceedings of the Ninth Conference of the International Society of Nubian Studies, August 21-26, 1998, Boston, Massachusetts, edited by T. Kendall. Boston, MA: Department of African-American Studies, Northeastern University.

Žába, Zbynêk. 1974. The Rock Inscriptions of Lower Nubia (Czechoslovak Concession). Vol. I Prague, Czech Republic: Charles University of Prague. 